\title{
Kan erfaringer med somatisk sykdom og skade føre til personlig vekst?
}

\section{Noen somatiske pasienter opplever positive personlige endringer etter svært belastende hendelser. For andre oppleves sykdommen bare som en byrde.}

\section{Torkil Berge}

Psykologspesialist

Voksenpsykiatrisk avdeling, Diakonhjemmet Sykehus

Bente Bull-Hansen

Lege

Voksenpsykiatrisk avdeling, Diakonhjemmet Sykehus

Elin Fjerstad

Psykologspesialist

Voksenpsykiatrisk avdeling, Diakonhjemmet Sykehus

\section{\begin{tabular}{llll} 
Mestring Psykologi $\quad$ Sykdom Rehabilitering \\
\hline
\end{tabular}}

\section{Hovedbudskap}

Begrepet «posttraumatisk vekst» beskriver hvordan forskjellige sykdomsbelastninger kan styrke en persons identitet og ha andre positive følger. Vi intervjuet en gruppe pasienter om negative og positive erfaringer forbundet med sykdom. Artikkelen presenterer noen av svarene vi fikk, og vi drøfter mulige uheldige konsekvenser av å løfte frem positive sider ved noe som er så negativt som sykdom vanligvis er. 
Mye av forskningen rundt psykologiske konsekvenser av somatisk sykdom og skade har vært rettet mot negative forhold, som svekket livskvalitet, angst, depresjon og posttraumatiske symptomer.

Samtidig har man også unders $\varnothing$ kt om sykdom og skade, og den etterfølgende omstillings- og rehabiliteringsprosessen, kan bidra til å styrke identitet og selvfølelse og ha andre positive følger for pasienten.

Sykdom og skade kan for eksempel få oss til å stanse opp og reflektere over eksistensielle spørsmål, over retningen livet har hatt til nå, og over hva vi synes er meningsfullt og vil prioritere i våre liv og relasjoner. Begreper som benyttes $i$ denne forskningstradisjonen, er «benefit finding» og posttraumatisk, stressrelatert eller psykologisk vekst (1).

\section{Metode}

Ved Enhet for psykiske helsetjenester i somatikken på Diakonhjemmet Sykehus intervjuet vi 35 pasienter om deres erfaringer med å håndtere sykdom i hverdagen, og om hvordan de opplevde at helsevesenet bidro til mestring. Vi benyttet et semistrukturert spørreskjema og spurte blant annet om negative og positive erfaringer forbundet med sykdommen.

Noen av pasientene svarte at de gjennom sykdommen hadde fått verdifulle erfaringer. En pasient sa: «Jeg er takknemlig for det livet som jeg før tok som en selvfølge.» En annen pasient uttrykte følgende: «Jeg har blitt flinkere til å ta vare på meg selv, jeg har prøvd og feilet og vet hva som fungerer.»

\section{三 «Sykdom og skade kan få oss til å stanse opp og reflektere over hva vi synes er meningsfullt og vil prioritere i våre liv og relasjoner.»}

Andre pasienter svarte derimot at de ikke kunne finne positive sider ved sykdommen, med dens kroppslige plager og påfølgende redusert funksjon og livskvalitet. Noen fortalte for eksempel at de hadde fått psykiske problemer og svekket selvfølelse i kjølvannet av sykdommen. En pasient sa: «Det er usikkerheten min som er det største problemet, at jeg ikke vet hvem jeg er lenger.» 
I det følgende kan du lese om forskning på posttraumatisk vekst ved somatisk sykdom og skade og hva pasientene la vekt på i intervjuene vi gjorde med dem. Avslutningsvis drøfter vi mulige uheldige sider ved å prøve å løfte frem positive sider ved noe som er så negativt og hemmende som sykdom og skade jo faktisk er.

\section{Hva er posttraumatisk vekst?}

Posttraumatisk vekst er positivt opplevde personlige endringer etter svært belastende hendelser. Veksten kan være i form av $\varnothing \mathrm{kt}$ personlig styrke, bedre relasjoner, nye prioriteringer, en ny og dypere mening i livet eller en $\varnothing \mathrm{kt}$ åndelig bevissthet.

Traumatiske hendelser kan rokke ved våre grunnleggende antakelser om verden som trygg, kontrollerbar og rettferdig (2). Det kan i sin tur bidra til emosjonell og kognitiv bearbeiding rettet mot å skape ny mening og styrket opplevelse av mestring (3).

\section{三 «Noen kan føle takknemlighet og til og med beundring for en kropp som tross alt fungerer gjennom sykdom og store påkjenninger.»}

Man kan sette større pris på livet, endre prioriteringer, bli mer opptatt av et nært og varmt forhold til andre, føle seg sterkere og se nye muligheter i livet (4). Noen kan føle takknemlighet og til og med beundring for en kropp som tross alt fungerer gjennom sykdom og store påkjenninger.

Spesielt under alvorlig sykdom er det jo kroppen som kjemper imot og holder ut. Studier av posttraumatisk vekst har for eksempel vært rettet mot pasienter med kreft (5) og hjertesykdom (6) og ved rehabilitering etter alvorlig skade (7).

Det er utviklet flere instrumenter for å måle posttraumatisk vekst, som The Stress-Related Growth Scale (8) og The Posttraumatic Growth Inventory (9). Disse instrumentene måler endringer i personlige og sosiale ressurser, livsfilosofi og mestringsstrategier, relasjoner til andre, personlig styrke, evne til å verdsette livet, og et nytt syn på religiøse eller eksistensielle spørsmål. 


\section{Kritikk av forskningstradisjonen}

Det er ikke avklart i forskningen om posttraumatisk vekst, slik det er blitt målt i studiene, gjenspeiler en genuin positiv endring av symptomer, livskvalitet eller funksjon hos pasientene. Studiene er basert på selvrapportering, og det som måles, er personens egenopplevelse av positiv utvikling (10).

I enkelte studier, blant annet av personer som opplevde bombingen av regjeringskvartalet i 2011 (11), er tidlig selvrapportert posttraumatisk vekst faktisk forbundet med en senere $\varnothing$ kning i selvrapporterte posttraumatiske symptomer. En person kan oppleve vekst og samtidig ha sterke negative ettervirkninger, kanskje særlig når den opplevde belastningen er høy.

Det er altså ikke noe entydig forhold mellom posttraumatisk vekst, livskvalitet og psykisk helse. Jo høyere stressbelastning pasienten opplever i forbindelse med en livstruende sykdom, desto høyere er ofte også rapportert posttraumatisk vekst.

\section{三 «En person kan oppleve vekst og samtidig ha sterke negative ettervirkninger, kanskje særlig når den opplevde belastningen er høy.»}

Man kan tilsvarende tenke seg at psykologisk velvære og ubehag gjenspeiler to separate dimensjoner, som kan være til stede uavhengig av hverandre for samme person på samme tid (12). På samme måte kan mental helse og mental lidelse forstås som to relaterte, men distinkte dimensjoner (13).

Det har av forskere på dette området også vært stilt spørsmål ved berettigelsen av hypotesen om «vekst gjennom lidelse». I Mangelsdorf og medarbeideres gjennomgang av 122 longitudinelle studier fant de at det ikke var mer vekst etter negative enn etter positive hendelser (14). Dette er funn som vi synes gjenspeiles i våre intervjuer.

\section{Hva sier våre pasienter?}

I intervjuene vi gjorde på Diakonhjemmet Sykehus om pasientenes erfaringer med å håndtere sykdom i hverdagen, la vi inn følgende spørsmål: «Noen opplever at det å bli syk er utelukkende negativt, mens andre etter hvert erfarer at det også har kommet noe positivt ut av det. Hvordan er dette for deg? Opplever du at det på noen måte har ført til noe positivt i ditt liv?» 
I det følgende vil vi trekke frem noen av svarene vi fikk, som illustrasjoner på både positive og negative erfaringer.

\section{Positive erfaringer}

En kvinne med både inflammatorisk mage-tarm-sykdom og revmatisk sykdom fortalte at hun hadde «perfekt pikesyndromet». Under sykdommen ble hun nødt til å lære seg å se livet på en ny måte, der hun ikke presset seg så mye: «Jeg må gjøre om veldig mye inne i hodet mitt. Tenke at det ikke er noe som heter halvveis, liksom, for noen ganger er det tilstrekkelig. Jeg begynte å leve livet mitt med en sunnere innstilling, og sluttet å se på meg selv som en unnasluntrer hvis jeg ikke presset meg til siste rest.»

En ung kvinne med barneleddgikt svarte: «Jeg tenker at alt gir både positive og negative erfaringer. Sykdommen er nok noe jeg har vokst ekstremt på. Jeg ville ikke vært den reflekterte personen jeg er den dag i dag, hvis jeg ikke hadde vært syk og hadde måttet ha så mye kontakt med voksne. Jeg ville ikke hatt muligheten til å være like reflektert over min egen tilværelse.»

\section{三 «Sykdommen er nok noe jeg har vokst ekstremt på.»}

Pasient

En mann med hjertesykdom svarte: «Ja, det har jeg gjort meg mange tanker om. Den første gangen jeg fikk infarkt, tenkte jeg med meg selv at du verden, det var egentlig i orden at jeg fikk det akkurat nå, for jeg hadde nettopp fått en liten unge. Jeg var arbeidsnarkoman, jobb, hus og penger, alt det tullet der, og jeg fikk stoppet opp og kunne se andre verdier. Jeg hadde en annen jente på fire år, som jeg nesten ikke kjente fordi jeg bare var ute og jobbet. Men det gikk ikke lange stunden før jeg var inne i den samme tralten igjen. Likevel følte jeg at jeg fikk andre verdier som betød mye mer, ikke minst det å prioritere tid.»

En kvinne med kreft og diabetes svarte: «Med en kronisk sykdom blir man kanskje litt klokere, tror jeg. Og man blir litt mer tolerant. Man aksepterer på en annen måte at folk ikke er perfekte.»

\section{«Med en kronisk sykdom blir man kanskje litt klokere, tror jeg. Og man blir litt mer tolerant.»}


En annen kvinne som også hadde kreft, sa: «Du får et helt annet perspektiv på livet, du forstår hva som er viktigst. Det er jo de nærmeste og de du er glad i. Og det å fortsette å være nysgjerrig, fortsette å lære ting og bli kjent med nye mennesker.»

En pasient med leddgikt svarte: «Jeg har fătt en litt annen identitet, og folk sier det til meg også. Før var jeg en villstyring, som levde i nuet, det var liksom bare én ting som gjaldt, og det var å bli best i idrett. Jeg er blitt litt mer moden og reflektert, kanskje.»

En ung kvinne med langvarig og livstruende sykdom svarte: «Jeg hadde jo aldri vært disse årene foruten. Det må jeg si, selv om det har vært helt jævlig, jeg har vokst mye på det, blitt en helt annen person. Mye sterkere enn jeg var før. Hvis jeg nå blir frisk snart, så har jeg et mye bedre utgangspunkt for livet videre.»

\section{Negative erfaringer}

Sykdom kan forandre kroppen dramatisk, både når det gjelder hvordan den ser ut, og hva den kan brukes til. Når man ikke lenger får til det man fikk til før, og mister sosiale roller, for eksempel ved sykefravær, kan identitetsopplevelsen svekkes.

En pasient med revmatisk sykdom sa: «Jeg ser ikke noe positivt i det. Absolutt ikke. Jeg prøver jo å finne tilbake til noen positive kvaliteter ved meg selv, for jeg har på en måte mistet meg selv.»

\section{$\equiv$ «Jeg ser ikke noe positivt i det. Absolutt ikke.»}

\section{Pasient}

En mann med inflammatorisk revmatisk sykdom hadde en tilsvarende tilbakemelding: «Ja ja, man burde jo velge å se det positive i ting. Men nei, jeg må si som sant er, at når det er på det mørkeste, så er ikke akkurat de positive tingene veldig fremtredende. De er ikke det.» 
En kvinne med hjertesykdom og sterke ryggsmerter la i sitt svar vekt på at hun hadde et lite barn, og at sykdommen påvirket foreldrerollen negativt: «Jeg har ikke kommet dit ennå. Jeg tror man kanskje kan bli litt flinkere til å se hva som er viktig, og ja, finne ut at man ikke kan klare alt. Men hvor positivt det er, vet jeg ikke. Jeg er medlem av en Facebookgruppe for folk som har hatt hjerteinfarkt, mest amerikanere, som liksom har fått et nytt liv og en ny mening med livet. Nei, jeg er ikke helt der. Hadde jeg bare hatt meg selv, og hatt voksne barn, så hadde det kanskje vært annerledes.»

En kvinne med diabetes og leddgikt svarte: «Jeg har sagt til venner at det som du ikke dør av, blir du sterkere av. Det har jeg også ofte sagt til meg selv. Men i en periode nå har jeg vært veldig plaget og hatt veldig mye vondt. Medisinene virker ikke, og legene sier at smerte er noe jeg må regne med. Da føler jeg liksom at nei, nå gidder jeg ikke, jeg vil ikke bli sterkere nå.»

En kvinne med inflammatorisk revmatisk sykdom svarte: «Nei, vet du, det har jeg ikke tenkt på. Sykdommen er på en måte bare noe jeg har fått. Jeg har vært mer opptatt av å overleve og klare meg og få det så greit som mulig, så det er vel mer det. Det har jeg ikke filosofert noe over.»

\section{$\equiv$ «Jeg skulle jo helst sett at jeg slapp.»}

Pasient

En kvinne med inflammatorisk mage-tarm-sykdom svarte: «Jeg vet ikke helt, jeg. Jeg synes jo ikke det er noe positivt å være dårlig. Jeg har hørt mange som sier det, at de skulle ikke vært den foruten, men det skulle gjerne jeg, altså. Det skulle jeg virkelig gjerne ha vært. Men det er klart at man tilpasser seg det man har, og jeg greier jo det godt også. Jeg er nå fortsatt glad og har det fint, så jeg går ikke rundt og er lei meg hver dag. Men jeg vet ikke helt hva som skulle være det positive. Jeg har møtt mange koselige folk, det har jeg gjort, og mange snille leger. Men jeg skulle jo helst sett at jeg slapp.

Det må jeg si, altså.»

\section{Implikasjoner for klinisk praksis}

Sykdommen i seg selv, og behandlingen pasienten må igjennom, kan bli både smertefull, utmattende og kvalmende. I tillegg kommer konsekvensene av sykdommen for funksjon, rolle, selvfølelse og identitet: Hvordan vil sykdommen påvirke livet mitt, familien og evnen til å ta vare på barna mine? Seksuallivet og søvnen kan bli påvirket, og økonomien kan bli dårligere. 
Sykdom kan vekke sterke følelser hos pasientene. Sykdom kan gi en følelse av å være fanget eller d $\varnothing \mathrm{mt}$, en følelse av bitterhet, sinne og sorg, og kanskje også maktesløshet eller håpløshet.

Evnen til motstandskraft, omstilling og psykologisk fleksibilitet blir satt på prøve. Samtidig føler altså noen at de har lært noe viktig om seg selv og om livet, og at de har vokst som menneske på det de har vært igjennom. Andre har en helt annen oppfatning, der sykdom og skade i sitt vesen oppleves som en negativ og kanskje også direkte nedbrytende erfaring.

\section{三 «Vi som helsepersonell må unngå å formidle en forventning om at sykdom kan bidra til vekst og utvikling.»}

Det kan som en del av behandling, pleie og omsorg være gunstig for noen pasienter å få anledning til å sette ord på lærerike erfaringer og identitetsfremmende prosesser i kjølvannet av sykdom og skade. Det kan bidra til å gjøre pasienten bevisst sin egen styrke og resiliens.

Samtidig må vi som helsepersonell unngå å formidle en forventning om at sykdom kan bidra til vekst og utvikling. Slike forventninger kan gi skyld- og skamfølelse, på samme måte som normative budskap om betydningen av «å akseptere sykdom» kan gi (15).

Kanskje spørsmålet vi stilte i intervjuet, som hovedregel ikke bør inngå i samtaler vi som helsepersonell har med pasienter. Da unngår vi å formidle holdninger i retning av at man bør «se det positive» i lidelse og smerte, som fort kan bli en ekstra byrde for pasienter som har mer enn nok av belastninger.

Det må være opp til den enkelte pasient selv å gi uttrykk for om han eller hun opplever å ha hatt en form for personlig vekst i kjølvannet av sykdommen, og eventuelt ønsker å ha det som et tema i samtalen.

\section{Referanser}

1. Tedeschi RG, Shakespeare-Finch J, Taku K, Calhoun LG. Posttraumatic growth. Theory, research, and applications.

New York: Routledge; 2018. 
2. Janoff-Bulman R. Shattered assumptions: towards a new psychology of trauma. New York: Free Press; 1992.

3. Bonnano GA. Loss, trauma and human resilience. American Psychologist. 2004;59:20-8.

4. Helgeson VS, Reynolds KA, Tomich PL. A meta-analytic review of benefit finding and growth. J Consult Clin Psychol. 2006;74(5):797-816.

5. Greszta E, Sieminska MJ. Patient-perceived changes in the system of values after cancer diagnosis. J Clin Psychol Med Settings. 2011;18(1):55-64.

6. Bluvstein I, Moravchick L, Sheps D, Screiber S, Bloch M. Posttraumatic growth, posttraumatic stress symptoms and mental health among coronary heart disease survivors. J Clin Psychol Med Settings. 2012;20(2):164-72.

7. Kampman H, Hefferon K, Wilson M, Beale J. «I can do things now that people thought were impossible. Actually, things that I thought were impossible»: a meta-synthesis of the qualitative findings on posttraumatic growth and severe physical injury. Can Psychol. 2015;56(3):289-94.

8. Park CL, Cohen LH, Murch RL. Assessment and prediction of stress-related growth. J Personal. 1996;64(1):71105.

9. Tedeschi RG, Calhoun L. The posttraumatic growth inventory: measuring the positive legacy of trauma. J Trauma Stress. 1996;9(3):455-71.

10. Frazier P, Tennen H, Gavian M, Park C, Tomich P, Tashiro T. Does self-reported posttraumatic growth reflect genuine positive change? Psychol Sci. 2011;20(7):912-9.

11. Blix I, Birkeland MS, Hansen MB, Heir T. Posttraumatic growth - an antecedent and outcome of posttraumatic stress: cross-lagged associations among individuals exposed to terrorism. Clin Psycholog Sci. 2016;4(4):620-8.

12. Zoellner T, Maercker A. Posttraumatic growth in clinical psychology - a critical review and introduction to a twocomponent model. Clin Psychol Rev. 2006;26(5):626-53. 
13. Westerhof GB, Keyes CLM. Mental illness and mental health: the two continua model across the lifespan. J Adult Dev. 2010;17(2):110-9.

14. Mangelsdorf J, Eid M, Luhmann M. Does growth require suffering? A systematic review and meta-analysis on genuine posttraumatic and postecstatic growth. Psychol Bull. 2019;145(3):302-38.

15. Berge T, Fjerstad E, Hyldmo I, Lang N. Håndbok i klinisk helsepsykologi. For deg som behandler pasienter med somatisk sykdom og skade. Bergen: Fagbokforlaget; 2019. 